\title{
Colicin Factors and Mitomycin-C
}

\author{
By K. G. HARDY* AND G. G. MEYNELL* \\ Guinness-Lister Research Unit, Lister Institute, \\ Chelsea Bridge Road, London, $S W$ I $W 8 R H$
}

(Received 6 July 1972)

SUMMARY

Mitomycin-C increased the titres of all of nine colicins tested, regardless of whether the colicin factor comprised a sex factor.

\section{INTRODUCTION}

Colicin titres have long been known to increase after exposing certain colicinogenic strains to ultraviolet radiation or to mitomycin-C (Jacob, Siminovitch \& Wollman, I952; Iijima, 1962). More recently, a comparison of the colicin factors, EI-K30, E2-P9, E3-CA38, $\mathrm{Ib}-\mathrm{P} 9$ and V-K94, suggested that the only factors which responded to mitomycin-C were those such as members of the $\mathrm{E}$ group, as distinct from the I and $\mathrm{V}$ groups, which lacked sex factors and were not self-transmissible (Herschman \& Helinski, 1967). However, it has since become clear that mitomycin- $\mathrm{C}$ does increase the titres of colicin specified by transmissible Col factors. This is evident from the behaviour of ColB-K98 and ColB-K I66 (Hausmann \& Clowes, I97I) and, moreover, of the I and V factors examined here.

\section{METHODS}

The difference between the original and the present results probably lies in details of technique. Originally, colicin titres were determined by killing the cultures with chloroform before titrating the culture as a whole (Herschman \& Helinski, 1967). However, colicins of the B, I and V groups are now known to be predominantly cell-bound (Hardy \& Meynell, 1972) and not to be consistently released for titration simply by chloroform treatment (Dowman \& Meynell, 1970). Even if the organisms are lysed with lysozyme, EDTA and a detergent like sarkosyl (Geigy Ltd, Manchester, 22), titres are misleadingly low because some colicin is inactivated by the detergent. The present method was therefore to treat cultures with ultrasonics followed by dilution (Table I), using a fresh pipette for each step to avoid falsely high titres, before determining the titre by the drop method as described in Dowman \& Meynell (1970).

Table I shows the colicin titres obtained $90 \mathrm{~min}$ after adding various concentrations of mitomycin-C to either $\mathrm{rec} A^{+}$(recombination-proficient) or recA cultures of Escherichia coli $\mathrm{KI} 2$ carrying various Col factors. In the $\mathrm{rec}^{+}$hosts, titres were invariably increased, regardless of whether the Col factor comprised a sex factor. The increases would probably have been greater with a longer period of incubation, as seen from Fig. I, which shows the behaviour of a $r e c A^{+}$strain carrying ColV-K 30 . In the $\operatorname{rec} A$ hosts, titres rose very little.

\footnotetext{
* Present address : Biological Laboratories, University of Kent, Canterbury, Kent.
} 


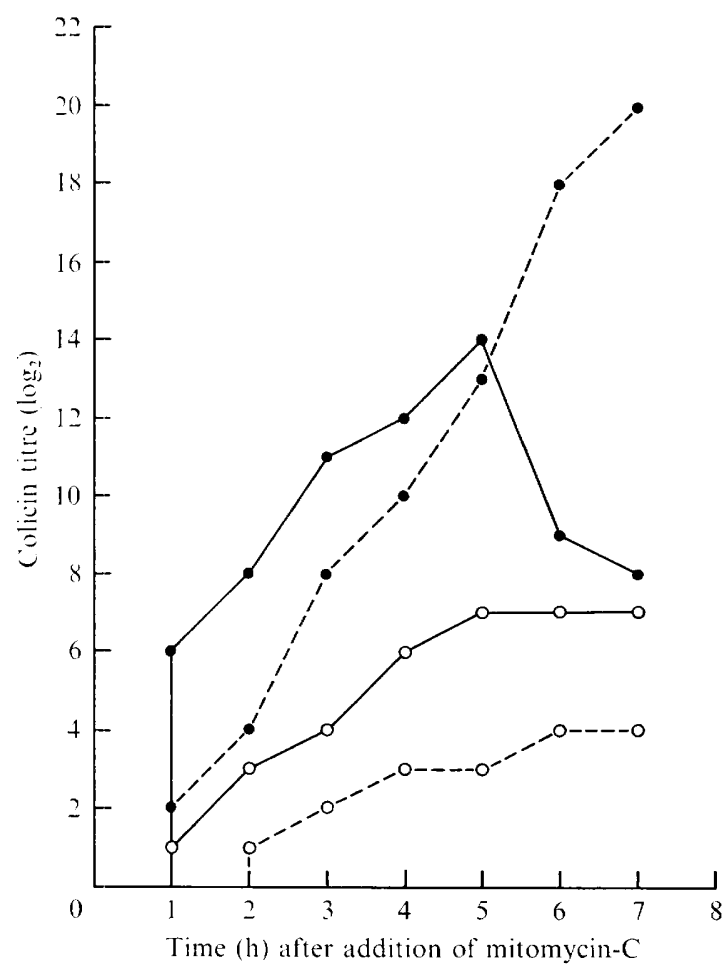

Fig. I. An unshaken $\mathrm{I} 8 \mathrm{~h}$ broth culture of Escherichia coli $\mathrm{KI} 2(\mathrm{KH} 308 \mathrm{ColV}-\mathrm{r}$ ColV-K 30 ) was diluted $\mathrm{I} / \mathrm{I} 00$ in fresh broth. On reaching $E=0 \cdot \mathrm{I}$, the culture was divided into two parts. Mitomycin- $C$ was added to one part to a concentration of $\mathrm{I} \mu \mathrm{g} / \mathrm{ml}$ : the other part served as an untreated control. Both cultures were then incubated at $37^{\circ} \mathrm{C}$ with shaking. Samples were removed hourly and centrifuged at $\mathrm{I} 600 \mathrm{~g}$ for $\mathrm{I} 5 \mathrm{~min}$. Cell-bound colicin was estimated after the deposited organisms had been resuspended in saline and disrupted with ultrasonics. Free colicin was estimated on the supernatant of the centrifuged culture. - - C - Cell-bound and free colicin, respectively, in the mitomycin-treated culture. $\bigcirc-\bigcirc, \bigcirc--\bigcirc$, Cell-bound and free colicin, respectively, in the untreated culture.

\section{Table I. Colicin titres after exposure to mitomycin- $C$}

The rec $\mathrm{A}^{+}$and $\mathrm{recA}$ strains were $\mathrm{ABI}{ }_{57}$ and $\mathrm{AB} 2463$, respectively. Col factors lacking their own sex factor were co-transferred by the sex factor, I-I 6 . Unshaken $\mathrm{I} 8 \mathrm{~h}$ cultures were diluted $\mathrm{I} / \mathrm{I} 00$ in fresh broth. On reaching $E$ of $0 . I$, mitomycin-C was added as shown. After a further 90 min at $37^{\circ} \mathrm{C}$, samples were disintegrated by ultrasonics: I $\mathrm{ml}$ culture was placed in a plastic tube $(77 \times 16 \mathrm{~mm}$ ) and treated for $5 \mathrm{~min}$ in an ultrasonic cleaning bath (Millipore Ltd, no. XX6600850). The preparation was then titrated by the drop method on agar containing nalidixic acid ( $50 \mu \mathrm{g} / \mathrm{ml})$, using a nalidixic-acid resistant indicator.

Titre in $\mathrm{rec} \mathrm{A}^{+} / \mathrm{rec} A$

$\begin{array}{lc}\begin{array}{l}\text { Colicin } \\ \text { factor }\end{array} & \begin{array}{c}\text { Comprises } \\ \text { sex factor }\end{array} \\ \text { B-K98 } & + \\ \text { EIa-I6 } & - \\ \text { EI-K30 } & - \\ \text { E2-P9 } & - \\ \text { Ia-CT4 } & + \\ \text { Ib-P9 } & + \\ \text { K-235 } & - \\ \text { V-K30 } & + \\ \text { V-K94 } & +\end{array}$

Concentration of mitomycin- $\mathrm{C}(\mu \mathrm{g} / \mathrm{ml})$

\begin{tabular}{|c|c|c|c|}
\hline 0 & 0.01 & 0.1 & I \\
\hline $32 / 8$ & $512 / 4$ & $256 / 2$ & $1024 / 8$ \\
\hline I $6 / 4$ & $64 / 8$ & $\mathrm{I} 28 / 4$ & $256 / 4$ \\
\hline $8 / 2$ & $16 / 4$ & I $28 / 2$ & I $28 / 4$ \\
\hline $28 / 4$ & $1024 / 16$ & $1024 / 8$ & $4096 / 4$ \\
\hline $8 / 4$ & $256 / 8$ & $128 / 2$ & I $28 / \mathrm{I}$ \\
\hline $16 / 8$ & $256 / 4$ & $2048 / 8$ & $\mathrm{I} 024 / 8$ \\
\hline $32 / 16$ & $5 \mathrm{I} 2 / 32$ & $5 \mathrm{I} 2 / 8$ & $1024 / 8$ \\
\hline $2 / 2$ & $8 / 2$ & $32 / 2$ & I $28 /<$ I \\
\hline $2 / 2$ & $8 / 1$ & $16 / I$ & I $6 /<$ I \\
\hline
\end{tabular}

$\begin{array}{ccrc}2 & 5 & \overbrace{r e c A^{+}} & \text {rec } A \\ 2048 / 4 & 64 / 4 & 64 & \text { I } \\ 16 / 8 & 256 / 4 & \mathrm{I} 6 & \mathrm{I} \\ 64 /<\mathrm{I} & 64 /<\mathrm{I} & \mathrm{I} 6 & 2 \\ \mathrm{I} 024 / 8 & 2048 / 4 & 32 & 4 \\ 64 /<\mathrm{I} & 64 /<\mathrm{I} & 32 & 2 \\ \mathrm{I} 28 / 4 & \mathrm{I} 28 / 2 & \mathrm{I} 28 & 2 \\ \mathrm{I} 28 / 4 & \mathrm{I} 28 / 2 & 32 & 2 \\ \mathrm{I} 28 / \mathrm{I} & 32 / \mathrm{I} & 64 & \mathrm{I} \\ 8 / 2 & 8 /<\mathrm{I} & 8 & \mathrm{I}\end{array}$

Maximum increase in 


\section{RESULTS AND DISCUSSION}

It appears therefore that the titres of all colicins tested here are increased by mitomycin-C, whether or not the Col factor is self-transmissible, provided the host is $r e c A^{+}$. The virtual absence of an increase in the $\operatorname{rec} A$ strains (Table I: Helinski \& Herschman, 1967) might suggest an analogy with the failure of ultraviolet radiation or mitomycin-C to induce prophages in rec $A$ lysogens (Brooks \& Clark, I967; Wing, 1968). However, unlike prophages, Col factors probably do not replicate vegetatively in $\mathrm{rec} \mathrm{A}^{+}$hosts after treatment with mitomycin-C. Hausmann \& Clowes (I97I) found that mitomycin-C increased the titres of colicins B-K98 and B-KI66 in hosts unable to make DNA at $42^{\circ} \mathrm{C}$; while Hardy \& Meynell (in preparation) found no more ColE2-P9 DNA after mitomycin-C treatment than in untreated controls. In discussing the effect of mitomycin-C on colicinogenic strains, it may therefore be useful to speak only of increased titres, rather than of increased colicin synthesis or of induction of Col factors, until more is known of the underlying mechanism.

Aided by a grant from the Central Research Fund, University of London.

\section{REFERENCES}

Brooks, K. \& ClaRK, A. J. (1967). Behaviour of $\lambda$ bacteriophage in a recombination deficient strain of Escherichia coli. Journal of Virology I, 283-293.

Bowman, J. E. \& Meynell, G. G. (1970). Pleiotropic effects of de-repressed bacterial sex factors on colicinogeny and cell wall structure. Molecular and General Genetics 109, 57-68.

Hardy, K. G. \& Meynell, G. G. (1972). Mechanisms of colicinogeny. Proceedings of the Biochemical Society 127, $69 P$.

Hausmann, C. \& Clowes, R. C. (I97I). Mitomycin C and temperature induction of colicin B in the absence of deoxyribonucleic acid synthesis. Journal of Bacteriology 1o7, 633-635.

Helinski, D. R. \& Herschman, H. R. (1967). Effect of rec mutations on the activity of colicinogenic factors. Journal of Bacteriology 94, 700-706.

Herschman, H. R. \& Helinski, D. R. (1967). Comparative study of the events associated with colicin induction. Journal of Bacteriology 94, 69I-699.

IJנImA, T. (1962). Studies on the colicinogenic factor in Escherichia coli KI2. Induction of colicin production by mitomycin C. Biken Journal $5, \mathbf{I}-8$.

Jacob, F., Siminovitch, L. \& Wollman, E. (1952). Sur la biosynthèse d'une colicine et sur son mode d'action. Annales de l'Institut Pasteur 83, 295-3I5.

WING, J. P. (1968). Integration and induction of phage P22 in a recombination-deficient mutant of Salmonella typhimurium. Journal of Virology 2, 702-709. 